\title{
POLITINIŲ PARTIJŲ TEISINIS REGLAMENTAVIMAS 1919-1940 METAIS LIETUVOJE
}

\author{
Kristina Ivanauskaitė \\ Mykolo Romerio universiteto Teisès fakulteto \\ Teises filosofijos ir istorijos katedra \\ Ateities g. 20, 08303 Vilnius, Lietuva \\ Telefonas (+370) 62275178 \\ Elektroninis paštas kristina.ivanauskaite@gmail.com \\ Pateikta 2013 m. sausio 22 d., parengta spausdinti 2013 m. lapkričio 26 d. \\ doi:10.13165/SMS-13-5-4-13 \\ Anotacija. Straipsnyje nagrinejjami teisés aktai, reglamentavę politiniu partiju steigi- \\ mąsi, aptariamas politinių partijų veiklos teisinis reglamentavimas, jo pokyčiai, nagrinejja- \\ mos šiu pokyčiu priežastys. Analizuojami administraciniai aktai, igyvendinantys politiniu \\ partiju veikla reglamentuojančius teisès aktus, identifikuojamas jų ryšys su politiniu reži- \\ mu. Atskleidžiami teisinio reglamentavimo skirtumai 1919-1926 m. ir 1926-1940 m., ap- \\ tariama valstybès administraciniu instituciju ir pareigūnu įtaka formuojamam teisiniam \\ reglamentavimui. Priimti politines partijas reglamentuojantys teises aktai analizuojami \\ valstybès instituciju administraciniu aktu ir objektyviosios realybes kontekste. Straipsnyje \\ atskleidžiamas politiniu partiju statusas de jure ir de facto aspektu. Aptariama skirtingais \\ valstybingumo etapais politiniu partiju juridinio statuso pokyčius lèmusios priežastys ir ju
} itaka šalies valstybingumui.

Reikšminiai žodžiai: draugija, politine partija, nepaprastoji padètis, teisinis reglamentavimas.

Socialinių mokslų studijos / Societal Studies

(c) Mykolo Romerio universitetas, 2013

(C) Mykolas Romeris University, 2013
ISSN 2029-2236 (print), ISSN 2029-2244 (online) http://www.mruni.eu/lt/mokslo_darbai/SMS/ http://www.mruni.eu/en/mokslo_darbai/SMS/ 


\section{Ivadas}

Po Pirmojo pasaulinio karo Lietuvai atgavus nepriklausomybę, susidare palankios teisinès aplinkybės pirmą kartą istorijoje reglamentuoti politines partijas Lietuvoje. Visuotinai sutariama, kad politine partija - bene vienintelis taip glaudžiai su valstybe ir jos valdymu susijęs socialinis junginys. Gal todėl partijų reikšmė demokratinès santvarkos valstybèms yra ypatingai svarbi. Šiame straipsnyje bus aptariama vieno iš socialinių junginių - politinių partijų - teisinis reglamentavimas.

Atsižvelgiant ị tai, kad valstybès vykdoma politika yra tiesiogiai priklausoma nuo susiklosčiusios politinės sistemos, kurią sudaro visos valstybejje veikiančios politinès partijos, norint tinkamai ịvertinti politinių partijų teisinị reglamentavimą, svarbu išnagrinèti ne tik tuo metu galiojusius teisès aktus, bet ir jų pagrindu priimtus administracinius aktus, jų ịtaką politinèms partijoms.

Šio tyrimo objektas - Lietuvos politinių partijų teisinis reglamentavimas tarpukaryje.

Mokslinio tyrimo tikslas - atskleisti Lietuvos politinių partijų teisinio reglamentavimo raidą 1919-1940 m.

Moksliniam tyrimui atlikti taikomi bendrieji mokslinio pažinimo metodai, kurių pasirinkimą nulèmé tyrimo objekto specifika ir siekis nustatyti objektyvią tiesą. Tyrimas atliktas taikant kokybinius metodus, tyrimui duomenys sukaupti duomenu rinkimo meto$d u$. Duomenys pasirinkti atsižvelgiant ị mokslinio tyrimo tikslą - ieškomi ir analizuojami tuo metu galioję teisès aktai, valdžios institucijų išleisti aplinkraščiai, paaiškinimai ir teisininkų, istorikų darbai, kuriuose analizuoti partinès sistemos reglamentavimo klausimai. Surinkti duomenys analizuoti šiais metodais: istoriniu, chronologiniu, loginiu-analitiniu, sisteminiu, teleologiniu ir lingvistiniu.

Politinès partijos sulaukè daug dèmesio iš ịvairių sričių mokslininkų. Jos buvo nagrinejjamos skirtinga apimtimi visais Lietuvos valstybingumo etapais. Politinių partijų nagrinejjimui yra būdingas discipliniškumas: daugiausiai dèmesio jos sulaukè iš politologų, Lietuvos partinę sistemą pasirinkusių kaip savo mokslinių tyrinejjimų sritị (A. Jokubaitis, A. Lukošaitis, L. Talat-Kelpša, A. Krupavičius, A. Ramonaitè, I. Vinogradnaitè); istorikų (A. Šapoka, M. Tamošaitis, L. Truska), rašiusių naujausiųjų laikų politinès Lietuvos istorijos klausimais; teisininkų (J. Bulavas, M. Maksimaitis, P. Leonas, V. Pavilonis, M. Romeris, E. Šileikis), orientavusių savo tyrinèjimus i̇ politinių partijų institucionalizavimo, jų veiklos klausimus, aptarusių valdžios teisètumo ir legitimumo problemas, nagrinèjusių valstybės politinio režimo sąsajas su politinių partijų reglamentavimu. Atsižvelgiant ị tai, kad šis tyrimas orientuotas ị tarpukario Lietuvos politinių partijų teisinio reglamentavimo atskleidimą, jam atlikti buvo analizuojami teisininkų ir teisininkų-istorikų mokslo darbai. Juos, atsižvelgiant ị mokslinių tyrimų atlikimo laikotarpị, būtų galima suskirstyti ị: nepriklausomos Lietuvos laikotarpiu (M. Romeris, P. Leonas), SSRS okupacijos periodu (J. Bulavas, V. Pavilonis, M. Maksimaitis) ir po nepriklausomybės atgavimo (M. Maksimaitis, E. Šileikis) rašiusius mokslininkus. Siekiant mokslinio tyrimo objektyvumo, šiame moksliniame tyrime pirmenybè teikiama mokslininkams, nagrinejusiems politinių partijų reglamentavimą nepriklausomos Lietuvos laikotarpiais. Publikacijos, išleistos SSRS okupacijos laikotarpiu, taip pat buvo analizuojamos, tačiau jos bus vertinamos, atsižvelgus ị to meto politines aplinkybes. Atsižvelgiant ị tai nagrinejjamai temai reikšmingi nepriklausomoje 
Lietuvoje rašiusio M. Romerio darbai: „Lietuvos konstitucinès teisès paskaitos“ (1937) profesorius analizavo politinio režimo įtaką partinès sistemos raidai, „Reprezentacija ir mandatas" (1926) - nagrinejo rinkimus, kaip rinkejų interesų atstovavimo problemą; ne mažiau svarbi ir P. Leono knyga „Teisès enciklopedijos paskaitos. Teisès sociologijos paskaitos. Raštai II tomas.“ (2005), parengta pagal jo 1922-1938 m. Kauno Vytauto Didžiojo universiteto Teisių fakultete dėstytų teisès enciklopedijos bei sociologijos kursų medžiagą, kurioje nagrinètos valstybės ir teisès sąvokos, jų tarpusavio ryšiai. Svarbiausias šių laikų politinių partijų teisinį reglamentavimą analizuojantis darbas - E. Šileikio monografija „Politinių partijų institucionalizavimas. Partijų steigimas, registravimas, teisès, veiklos sustabdymas ir nutraukimas“ (1997), kurioje buvo aptartas politinių partijų reglamentavimas tarpukario konstitucijose.

M. Romeris vertindamas tokią situaciją, kai vos keli mokslininkai politines partijas tyrinėjo juridiniu aspektu, išreiškė nuostabą, kad „Atsižvelgiant ị svarbų politinių partijų vaidmenị moderniame politiniame gyvenime, galima būtų laukti gausingos literatūros šiuo klausimu. Tuo tarpu kažkodèl yra atvirkščiai. Politinių partijų problema <...> valstybès ir viešosios teisès moksle yra apleista. ${ }^{\text {"1 }}$

Šiame straipsnyje aptariami pirmieji bandymai reglamentuoti politines partijas nepriklausomoje Lietuvoje, daugpartinès sistemos formavimosi prielaidas, analizuojami po tautininkų perversmo, įvykusio 1926 m., teisinio reglamentavimo pokyčiai, sudarę sąlygas šalyje įsitvirtinti vienpartinei sistemai.

\section{Politinių partijų teisinis reglamentavimas Lietuvoje 1919-1926 m.}

P. Leonas rašè, kad politinès partijos susidaro „tiktai ten, kur yra nors minimalių politinès laisvès garantijų “2 , nes „diktatūra <...> negali gyvuoti šalia politinès laisvès“3. Politinių partijų tikrasis poreikis atsiranda, kai egzistuoja minties, susirinkimų ir asociacijų laisvè. Tik šalyje susiklosčius tokiai situacijai, asociacijų laisvė gali būti konkretizuota ir materializuota ${ }^{4}$. Konstitucionalistai vieningai linkę sutarti, kad būtent nuo režimo tiesiogiai priklauso politinių partijų reglamentavimas, jų veikimo laisvès ribos ir pareigos, individo teisès ir pareigos ${ }^{5}$. Politinès partijos veiklos ribos nustatomos teisès aktuose, kurie tiesiogiai yra susiję su politiniu režimu, kuris nubrèžia politinių partijų veiklos laisvès ribas $^{6}$. Mokslininkai iš esmès vieningai sutaria dèl standartų, kuriems esant, galima kalbèti bent apie minimalią demokratiją šalyje. Bendrąja prasme demokratiją, kaip prielaidą minimalioms politinėms laisvėms, galima būtų charakterizuoti kaip sistemą, užtikrinančią,

1 Römeris, M. Valstybè. II tomas. Vilnius: Pradai, 1995, p. 163-164, 170.

2 Leonas, P. Teisès enciklopedijos paskaitos. Teisès sociologijos paskaitos. Raštai. II tomas. Vilnius: Teisinés informacijos centras, 2005, p. 120.

$3 \quad$ Ibid.

4 Marabuto, P. Les partis politiques et les mouvements sociaux sous la IV République. HistoriqueOrganisation. Doctrine - Activité. Paris: Librairie du Recueil Sirey, 1948, p. 3.

$5 \quad$ Ibid., p. 5.

6 Bonaudi, E. Pricipii di Diritto Pubblico. Torino: Unione tripografico - editrice torinese, 1936, p. 512 . 
kad vyriausybės veiksmai atitiktų piliečių valią, t. y. ji užtikrina laisvę steigti organizacijas ir jungtis ị jas; žodžio laisvę; teisę balsuoti ir būti renkamam; teisę politikos lyderiams varžytis dẻl jų palaikymo ir balsų; alternatyvių informacijos šaltinių egzistavimą; laisvus ir sąžiningus rinkimus; kad institucijos, vykdančios vyriausybės programą, priklausys nuo balsų ir kitų išreiktų preferencijų ${ }^{7}$. Vadinasi, tik valstybeje, kurioje išvardinti standartai yra "gyvi“, galima kalbeti apie demokratiją ir realų politinių partijų, kaip vieno iš svarbiausių demokratijos elementų, vaidmenị valstybeje. Todèl natūralu, kad pirmosios lietuviškosios politinès partijos pradejo organizuotis ir steigtis tada, kai valstybeje sustiprèjo demokratinès vertybės ir susidarè sąlygos, leidžiančios užtikrinti bent minimalią jų apsaugą.

Konstitucionalistai linkę išskirti du pagrindinius politinių partijų steigimo būdus. Valstybė gali: pripažinti partijas, šis pripažinimas gali būti kaip pripažinimas fakto, kuris egzistuoja konkrečioje valstybejje; arba gali priimti normas, nustatančias politinių partijų veiklos tvarką, pripažinti jų ịtaką, t. y. siekiant išlaikyti tikrąji ryšş su valstybe, valstybė priskiria partijoms reikšmingas teises, susijusias su politine veikla ${ }^{8}$.

Lietuvos Respublikai tapus nepriklausoma, ìstatymų leidejjas tarsi nuejjo trečiuoju keliu. Atsisakydamas pripažinti de facto egzistuojančias politines partijas, jis, nors ir tiesiogiai politinių partijų neịvardindamas, nustate joms juridinius pagrindus ịsisteigti. Tarpukario Lietuvos konstitucijose politinès partijos neminimos, apie jas netiesiogiai užsimenama tik deklaruojant laisvą jungimąsi ị draugijas, jei jų tikslai ir vykdomosios priemonès nèra priešingos baudžiamiesiems ịstatymams.

Siekdama reglamentuoti visuomenines organizacijas, laikinoji Vyriausybẻ 1919 m. spalio $10 \mathrm{~d}$. prièmė İstatymą apie draugijas. Visuomeninių organizacijų veiklą reguliavęs Istatymas apie draugijas pavedè jas prižiūrèti vidaus reikalų institucijoms. Pirmasis draugijų ịstatymo straipsnis nustatė draugijų sąvokos apibrèžimą: „Draugija (sąjunga, partija ir kt.) - yra susivienijimas kuopon kelių asmenų, pasistačiusių kokị nors aiškų, bendro darbo tikslą ir, tam tikslui atsiekti, sutartinai, tam tikrais įstatais, dirbančių. ${ }^{\text {"9 }}$ M. Romeris politines partijas apibūdino panašiai. Jis siejo jas su dirbtinio pobūdžio draugijomis, kurios kyla iš sąmoningos ir valingos jų steigejjų valios, kurie siekia patenkinti tam tikros grupès interesus, ir sukuriamos statutų pagrindu ${ }^{10}$. Draugijų i̇statymo 5 straipsnis nustatė pareikštinę - normatyvinę draugijų steigimo tvarką, numatė, kad pranešimas, steigiant draugiją, turi būti paduodamas apskrities viršininkui, su notaro, milicijos viršininko arba savivaldybès įstaigos patikrintais steigèjų parašais, kuriuose turi būti pažymėtas jų vardas, pavardè, užsièmimas ir gyvenamoji vieta. Atkreiptinas dèmesys, kad šio įstatymo tame pačiame straipsnyje yra minimos dvi juridine prasme skirtingos sąvokos, t. y. „pranešimas“ ir „,prašymas“. Pirmoji sąvoką, reiškianti tik formalų tam tikrų institucijų informavimą, painiojama su sąvoka, reiškiančia oficialų kreipimąsi ị instituciją, prašant administracinès paslaugos - išduoti leidimą, dokumentą, patvirtinantị tam tikrą juridinị faktą; priimti

7 Beigbeder, Y. International monitoring of plebiscites, referenda and national elections. Selfdetermination and Transition to Democracy. International Studies in Human Rights Volume 32. London: Martinus Nijhoff Publishers, 1994, p. 25.

8 Bonaudi, E., supra note 6, p. 499.

9 İstatymas apie draugijas. Laikinosios Vyriausybès žinios. 1919, Nr. 15. 
administracinị sprendimą, kuriame išreiškiama institucijos valia ir pan. Šis įstatymo leidèjo paliktas sąvokų netikslumas sudare prielaidas įstatymą interpretuoti dviprasmiškai. Pavyzdžiui, Kauno apskrities viršininkas atsisakė registruoti draugiją, nes „prie pareiškimo nèra pristatyta leidimas apie skyriaus registravimą“. Ginčas kilo dèl to, kad buvo skirtingai interpretuojama İstatymo apie draugijas 22 straipsnyje suformuluota norma, numatanti, kad draugijos skyriui ịregistruoti užtenka prie pareiškimo pristatyti draugijos įregistravimo leidimą ${ }^{11}$. Toks teisès aktuose esančių sąvokų nevienodumas „užprogramavo“ ginčus dèl normų taikymo ir sudarė prielaidas jas dviprasmiškai interpretuoti ateityje.

Istatymas numatė organizacijų steigimosi tvarką: kiekvienos visuomeninès organizacijos įstatus turèjo registruoti komisija, susidedanti iš apskrities viršininko, kuris buvo jos pirmininkas, apskrities komiteto nario ir taikos teisejjo. Nustatyta, kad komisija peržiūri įstatus, o radus įstatuose trūkumų, raštu praneša steigèjams apie juos. Steigejai per dvi savaites turi teisę trūkumus pašalinti. Šiam terminui pasibaigus, komisija priima galutini sprendimą dèl trūkumų pašalinimo. İstatymas numatè, kad komisija priima sprendimą dèl įstatų registravimo arba neregistravimo. İstatai, komisijos pripažintini registruotinais, apskrities viršininko įrašomi ị rejestrą, o atmestinais - grąžinami steigejams, nurodant priežastis, dèl kurių jie negali būti ịregistruoti. Analizuojant galimus atsisakymo registruoti draugijos ịstatus pagrindus, išskirtinas pagrindinis - ịstatai negali būti ịregistruoti, nes neatlikti visi İstatymo apie draugijas 2 ir 5 straipsnių reikalaujami formalumai ${ }^{12}$. Vidaus reikalų ministerijos Piliečių apsaugos departamento Juridinė komisija išleido paaiškinimus, kokius reikalavimus turi atitikti draugijų ịstatai, kad jie galètų būti pripažịstami tinkamais registruoti. Juose nurodyta, kad draugijų ịstatai privalo būti surašyti taisyklinga lietuvių kalba, parašai steigèjų po prašymu turi būti notaro patikrinti, sumokètas nustatyto dydžio žyminis mokestis ${ }^{13}$. Komisijai prièmus sprendimą registruoti draugijos įstatus, apskrities viršininkas apie draugijos ịsikūrimą paskelbia „Laikinosios Vyriausybès žinio$\mathrm{se}^{\text {“. }}$.

Istatymas apie draugijas ịtvirtino bendruosius demokratinès, teisinès valstybès saugiklius. Pavyzdžiui, 28 straipsnis uždraudè dalyvauti neịregistruotų draugijų veikloje, 29 straipsnis - steigti draugijas, kurių tikslas priešingas Valstybės baudžiamiesiems ịstatymams. Apskrities viršininkas ir Vidaus reikalų ministerijos Piliečių apsaugos departamentas galejo sustabdyti bet kurios organizacijos veiklą, jei jos veikla nukreipta prieš Lietuvos Respublikos įstatymus, o minètoji komisija - uždrausti organizaciją, jei ši nesilaiko savo įstatų. Tai, kas įstatymo prasme būtų laikoma nesilaikymu savo ịstatų, įstatymas nedetalizavo, palikdamas dispozicijos teisę spręsti įstatymą vykdantiems pareigūnams.

Pasakytina, kad iki İstatymo apie draugijas įsigaliojimo galiojo tik deklaratyvios konstitucinès nuostatos, laiduojančios draugijų ir sąjungų laisvę. Nesant priimto teisès akto, reglamentuojančio pasinaudojimo šia teise galimybes, de facto ši teisè buvusi „ne-

11 Kultūros švietimo draugijos 1927 m. rugpjūčio 18 d. raštas Piliečių apsaugos departamento direktoriui. Lietuvos centrinis valstybès archyvas. F. 394, ap. 15, b. 97, 1. 13.

12 Generalinio štabo Rikiuotès skyriui 1919 m. lapkričio 10 d. raštas Nr. 2762. Lietuvos centrinis valstybès archyvas. F. 394, ap. 3, b. 799, 1. 16.

13 Vidaus reikalų ministerijos Piliečių apsaugos departamento direktoriaus $1920 \mathrm{~m}$. rugsèjo $9 \mathrm{~d}$. raštas Panevėžio apskrities viršininkui Nr. 1828. Lietuvos centrinis valstybės archyvas. F. 394, ap. 3 , b. $799,1.66$. 
gyva“. Darytina išvada, kad šiuo įstatymu buvo sukurtas juridinis mechanizmas, numatęs procedūras politinių partijų steigimuisi, sudarytos juridinès sąlygos formalizuoti pirmųjų lietuvių politinių partijų ịsisteigimą.

Apibendrinant pasakytina, kad ịstatyme buvo įtvirtintas vienas iš pagrindinių demokratinès valstybès - laisvas politinių partijų steigimosi - principas. Dar daugiau - ịvestas reglamentavimas nustatė daugpartinès demokratinès politinės sistemos ir parlamentinès respublikos principus, o kartu su rinkimus reglamentuojančiais teisès aktais buvo ịtvirtinti aukščiausios valstybès valdžios organizavimo visuotinių rinkimų būdu, aukščiausios valdžios, piliečių atstovybès - parlamento - viršenybės ir valdžios padalinimo principai. Istatymas sudarè visiems vienodas sąlygas vadovaujantis galiojančiais teisès aktais steigti politines partijas, joms dalyvauti politinejje kovoje dèl valdžios pagal apibrèžtas ir visiems iš anksto žinomas taisykles. Priimti teisès aktai galètų būti vertinami kaip teisinis $1920 \mathrm{~m}$. balandžio mėnesị vykusių Steigiamojo Seimo rinkimų pamatas, o jų pagrindu įsteigtos politinès partijos, kovodamos dèl valdžios demokratiniuose rinkimuose, formavo šalyje „demokratijos užtikrinimo priemonę - daugiapartiškumą "14, t. y. daugpartinę sistemą, kurioje daugiau nei dvi partijos gali realiai konkuruoti dèl teisès sudaryti vyriausybę. Nepaisant to, kad šiam ịstatymui buvo būdingas ir itin liberalus draugijų ir sąjungų laisvès varžymo reglamentavimas, buvo palikta plati diskrecijos teisè vidaus reikalų sistemos administracijos darbuotojams ir pareigūnams priimti sprendimus dèl draugijų ir sąjungų laisvės varžymų.

Apibendrinant galima būtų pritarti M. Romerio nuomonei, kuris analizuodamas šio laikotarpio teisinị reglamentavimą yra konstatavęs, kad 1918-1926 m. Lietuvos laikotarpis režimo atžvilgiu buvo demokratiškas ${ }^{15}$. Politinių partijų steigimo ir veiklos teisinis reglamentavimas 1919-1926 m. vertintinas kaip atitinkantis svarbiausius demokratinès valstybès požymius: juridiškai ịtvirtintas laisvas draugijų - politinių partijų - steigimas ir jų veikla, tautos suvereniteto ir valdžių atskyrimo principai. Kita vertus, E. Šileikis analizuodamas politinių partijų reikšmès suvokimą tarpukaryje yra pastebėjęs, kad „,reaguojant ị Vokietijos nacionalsocialistų ir TSRS komunistų partijų diktatūrų padarinius, Vakarų valstybės <...> politines partijas teisiškai išskyrè iš kitų socialinių ne komercinių (pelno nesiekiančių) susivienijimų, t. y. konstituciškai ịvertino ypatingą politinių partijų (o ne draugijų ir sąjungų!) funkcinę paskirtị ir jai konkretizuoti prièmé specialias teisès normas $<\ldots>$. Todèl galima suprasti, kodèl tokių sąvokų nevartojo nei M. Römeris, nei kiti tarpukario Lietuvos jurisprudencijos atstovai"16. Lietuvoje, kaip Vakarų šalyse, politinių partijų, kaip tarpininkių tarp visuomenès ir valstybės valdžios, reikšmė ir jų įtaka formuojant ir išreiškiant piliečių valią buvo pradèta suvokti per Europą nuvilnijus nedemokratinių režimų bangai. O iki tol apie politines partijas tiek konstituciniu, tiek įstatymo, tiek ir moksliniu lygiu vengta kalbèti.

Primintina, kad visos Lietuvos tarpukario konstitucijos vienaip ar kitaip kalbejjo apie galimybes varžyti konstitucines žmogaus teises ir laisves. Jose pagrindinè priemonė pi-

14 Pavilonis, Vl. Buržuazinio demokratinio režimo Lietuvoje klausimu. Lietuvos TSR aukštujų mokyklu mokslo darbai. Teisé. 1966, VI: 35.

15 Romeris, M. Lietuvos konstitucinés teisés paskaitos. I d. Kaunas, 1937, p. 174-177.

16 Šileikis, E. Politinių partijų instucionalizavimas. Vilnius: Onė, 1997, p. 10. 
liečių demokratinėms teisèms ir laisvėms varžyti buvęs nepaprastosios padėties taikymo ịtvirtinimas konstituciniu lygmeniu. Galimybė taikyti nepaprastąją padėtị ir pagrindinès to taikymo pasekmès buvo užfiksuotos pagrindiniuose šalies įstatymuose: $1920 \mathrm{~m}$. birželio 10 d. Laikinosios Lietuvos Valstybès Konstitucijos 16 straipsnis visiems Lietuvos piliečiams laidavo spaudos, žodžio, susirinkimų, draugijų laisvę, tačiau kartu numatė, kad karo metu, taip pat Valstybei gresiančiam pavojui pašalinti konstitucinès garantijos i̊statymų būdu gali būti sustabdytos; 1922 m. Lietuvos Valstybės Konstitucijos 32 straipsnis reglamentavo, kad karo ar kurią kitą nepaprastąją padèti gali įvesti respublikos prezidentas, o ši aktą turi patvirtinti Seimas ne tik „kilus karui, ginkluotam sukilimui“, bet ir atsiradus ,kitokiems pavojingiems neramumams“. Detaliau karo padèti reglamentavo $1919 \mathrm{~m}$. kovo $5 \mathrm{~d}$. Ypatingi valstybès apsaugos ịstatai ${ }^{17}$, kurie mokslininkų buvo kritikuojami dẻ jų normų platumo, kurios faktiškai ịteisino karo komendantų „savivalę, taikant administracines prievartos priemones bei paneigiant proklamuotąsias <...> demokratines teises ir laisves"18. Karo komendantų galioje buvo ne tik imtis prievartos priemonių ne vien prieš asmenis, bet ir prieš spaudą, draugijas, pramonès ir prekybos įstaigas: sustabdyti spaudos leidinius, drausti susirinkimus, uždaryti ịstaigas. Naudodamiesi teise leisti privalomuosius įsakymus, karo komendantai paskelbe taisykles, kuriomis draugijų bei organizacijų veiklos kontrolę priskyrè savo kompetencijai. Pavyzdžiui, Raseinių apskrities karo komendanto $1920 \mathrm{~m}$. sausio $24 \mathrm{~d}$. įsakymas ịpareigojo visas draugijas, organizacijas ir profsąjungas pristatyti į komendantūrą savo statutus, programas, narių sąrašus; buvo ịpareigotos pranešti komendantūrai apie visus naujai ịstojusius narius, joms buvo uždrausta be komendanto leidimo daryti kokius nors pakeitimus savo statutuose ${ }^{19}$. Tokia juridinè situacija susidarė dèl to, kad Ypatinguose valstybės apsaugos įstatuose buvo gausu neapibrèžtų normų, suteikiančių komendantams vadinamąją diskrecinę galią, t. y. leidusių veikti savo nuožiūra. Pasak Vyriausiojo Tribunolo, Ypatingi valstybės apsaugos istatai ,tik bendra forma nurodo karo komendantams, kad jie gali griebtis represijos prieš visa, kas pavojinga visuomenès tvarkai arba kariuomenei, ir tas pavojingumas pavestas spręsti pačiam karo komendantui" ${ }^{20}$. Itstatų normų platumas ir neapibrèžtumas davė galimybę karo komendantams savo įsakymais papildyti ir konkretizuoti jas, atsižvelgiant $\mathfrak{i}$ momento keliamus ,uždavinius“.

Karo padètis valstybejje skelbta nuolatos. Teritoriniu atžvilgiu jos taikymas buvo kiek apribotas tik rengiantis Steigiamojo Seimo, vèliau - pirmojo Seimo rinkimams. Tiesa, nors buvo priimti teisès aktai, kuriais karo padètis buvo apribota ${ }^{21}$, bet tai telietė tik dali Lietuvos, be to, jie nebuvo nuosekliai vykdomi. Reikia pripažinti, kad Lietuva pirmuosius savo valstybingumo daigus skleidè itin sudètingomis aplinkybėmis: Europoje ką tik buvo

17 Ypatingi valstybès apsaugos ịstatai. Laikinosios Vyriausybės žinios. 1919, Nr. 5-55.

18 Maksimaitis, M. Karinių-administracinių organų savivalès įteisinimas Lietuvoje 1919-1926 m. Ypatingais valstybės apsaugos ịstatais. Lietuvos TSR mokslu akademijos darbai. Serija A, Nr. 1(12). Vilnius: Valstybinė politinès ir mokslinès literatūros leidykla, 1962, p. 21.

19 Ibid., p. 37.

20 Vyriausiojo Tribunolo 1924-1933 metų visuotiniųjų susirinkimų nutarimų rinkinys, 12. Kaunas, 1933.

21 İsakymas. Laikinosios Vyriausybès žinios. 1920, Nr. 20-253; İstatymo karo stoviui ịvesti pakeitimas. Vyriausybès žinios. 1922, Nr. 105-823. 
pasibaigęs Pirmasis pasaulinis karas; rytines sienas puolè sovietinė Rusijos armija; iki 1919 m. rudens krašte vis dar buvo pralaimėjusios karą Vokietijos kariai, kurių dalis vèliau perèjo ị bermontininkų gretas ir mégino užimti Lietuvos teritoriją; vyko kariniai konfliktai dèl Lietuvos sienų. Atsižvelgiant ị tokią situaciją šalyje, natūralu, kad nepaprastosios padèties taikymas buvo neišvengiamas, norint stabilizuoti padètị šalyje.

Nuolat taikoma karo padètis sudarè galimybes teisètai riboti Konstitucijoje ịtvirtintas teises ir laisves, tarp jų - laisvą politinių partijų steigimąsi ir veikimą, politines teises. Kita vertus, kiek de facto šiomis galimybėmis buvo pasinaudojama, priklausė tik nuo pareigūnų, kurie disponavo plačia diskrecijos teise priimti sprendimus dèl šių teisių tolesnio likimo. Reikia pripažinti, kad nors pareigūnai disponavo plačiais igaliojimais, jie nebuvo linkę piktnaudžiauti turimomis teisėmis.

Darytina išvada, kad nors konstituciniai aktai netiesiogiai deklaravo laisvą politinių partijų steigimąsi ir veikimą, tačiau šie teisès aktai neturètų būti vertinami atsietai, neatsižvelgiant ị visą tuo metu galiojusių Lietuvos Respublikos teisès aktų sistemą. Dèl to, nepaisant ịstatymo leidejo bandymų ịtvirtinti demokratijos minimaliuosius standartus, atitinkančius politinių partijų steigimosi ir jų veiklos principus, nepaprastosios padèties veikimo nuolatinumas ir jos teisinio reglamentavimo netobulumas, galiojęs politinių partijų reglamentavimas turètų būti vertinamas kaip, nors iš pirmo žvilgsnio atitinkantis minimalius demokratinès valstybės standartus, tačiau neužkertantis kelio galimiems piktnaudžiavimams teise.

\section{Politinių partijų teisinis reglamentavimas Lietuvoje 1926-1940 m.}

Po 1926 m. gruodžio 17 d. perversmo valdžią savo rankose sutelkè tautininkai, kurie buvo aktyvūs daugpartinès sistemos oponentai, raginę , pertraukti visus ryšius su nelemta praeities praktika“, kai ,valdo ne tauta, bet partijų centro komitetai“22. Šalyje pamažu pagarbą politinès laisvès principui pradėjo keisti jo reikšmès menkinimas, jis imtas tapatinti su tautos skaldymu ir supriešinimu. Šalies prezidentas viešai deklaravo nepasitenkinimą daugpartine sistema. Jo nuomone, daugiapartiškumas kenkia tautos vienybei, o jos trūkumas sukelia visas pagrindines šalies bẻdas. Buvo kritikuojamos ,iš svetur atsineštos partijų programos, skaldančios mūsų vieningą tautą “23. Vadovaujantis šiais motyvais, pradèta vykdyti nauja valstybės politika buvo nukreipta prieš politines partijas.

Nepaisant to, kad 1922 m. Lietuvos Valstybės Konstitucija faktiškai nustojo galiojusi nuo 1926 m. gruodžio 17 d. perversmo momento, tačiau tautininkai vengė Konstitucijos veikimą ex lege sustabdyti. Maža to, deklaruodami tolesnį Konstitucijos veikimą, jie kritikavo jos netobulumą, daug rašè apie būtinumą ją keisti ${ }^{24}$. Visiškai ignoruodama teisètą konstitucijos keitimo tvarką, tautininkų Vyriausybè 1928 m. gegužès 25 d. oficialiai paskelbė Prezidento dekretuotą dokumentą, pavadintą Lietuvos Valstybės Konstitucija ${ }^{25}$, kuris turèjo demokratinėms konstitucijoms būdingą formą. Nepaisant jos prièmimo 
aplinkybių, Konstitucija atkartojo 1922 m. Konstitucijos nuostatas, kurios skelbė: žodžio ir spaudos laisvę (16 straipsnis), laisvę daryti susirinkimus (17 straipsnis), draugijų ir sąjungų laisvę (18 straipsnis).

Tad nors šalyje po perversmo tautininkų valdžia iš karto neprièmė sprendimų, keičiančių teisinę sistemą iš esmès (de jure liko galioti tiek 1922 m. Konstitucija, tiek kiti pagrindiniai teisès aktai), tačiau vis dèlto šalyje ịvyko pokyčiai, kurie buvo pasiekti ịvedus nepaprastąją padètị, subtiliai manipuliuojant netobulomis teisès aktų nuostatomis. Karo stovis visoje Lietuvoje buvo panaikintas tik 1926 m. liepos 2 d. (išskyrus vieno kilometro zoną prie demarkacinès linijos), tačiau nuo perversmo dienos - $1926 \mathrm{~m}$. gruodžio $17 \mathrm{~d}$. - karo stovis vèl buvo visoje Lietuvoje ịvesta atskirų karininkų bei karo komendantų ịsakymais ir post factum tų pačių metų gruodžio 20 dieną A. Smetonos ir A. Voldemaro aktais sankcionuota $^{26}$. Nuolatinis karo stovis sudarè juridines prielaidas riboti Konstitucijoje ittvirtintas pagrindines žmogaus teises ir laisves.

Pažymètina, kad po perversmo buvo padaryti nepaprastosios padèties reglamentavimo konstituciniai pakeitimai: nors 1928 m. Konstitucijos 34 straipsnis ${ }^{27}$, reglamentavęs nepaprastosios padèties ịvedimą šalyje, iš esmès atitiko $1922 \mathrm{~m}$. Konstitucijos 32 straipsnį ${ }^{28}$, tačiau esminiu pasikeitimu buvę tai, kad 1922 m. Konstitucijos 34 straipsnyje buvo atsisakyta šių žodžių: ,ir tuo pat metu apie visa tai turi pranešti Seimui, kuris tą Vyriausybės žingsnị tvirtina arba atmeta. “ Šių žodžių išbraukimas iš Konstitucijos iš esmès pakeitė pačią garantijų sustabdymo procedūros esmę, taip suteikiant Prezidentui dar daugiau galių. Nors 1922 m. Konstitucija numaté, kad esant tam tikroms sąlygoms ir Ministrų kabinetui pasiūlius, sustabdyti konstitucines garantijas galèjo RespublikosPrezidentas, tačiau jo aktas nebuvęs galutinis, nes dar jam reikejjo Seimo ratifikacijos. Tuo tarpu 1928 m. Konstitucija, priešingai nei 1922 m. Konstitucija, numate, kad šis Prezidento aktas yra galutinis, nebuvo numatyta šio akto ratifikacijos procedūra Seime. Atsižvelgiant i tai reiktų pritarti M. Romerio vertinimui, kad parlamentinė kontrolė 1928 m. Konstitucijoje buvo ženkliai silpnesnè (lyginant su 1922 m. Konstitucijoje ittvirtinta), „,nes jos priemonèse nèra tiek energijos, kaip kad buvo" ${ }^{29}$. Vertinga M. Romerio pastaba ir apie tai, kad 1928 m. Konstitucijos 34 straipsnis yra skyriuje, reglamentuojančiame Seimą, tuo tarpu jis jokio tiesioginio ar netiesioginio ryšio su Seimu neturejjo, tačiau šis straipsnis buvo tame pačiame skyriuje, kaip buvo 1922 m. Konstitucijoje. Darytina išvada, kad 1928 m.

26 Karo stovio ịvedimo aktas. Vyriausybès žinios. 1926, Nr. 242-1582.

27 Kilus karui, ginkluotam sukilimui ar kitokiems pavojingiems neramumams valstybeje, Ministeriu Kabinetui pasiūlius, Respublikos Prezidentas gali visoje arba tam tikrose jos dalyse ịvesti karo arba kita kuria nepaprasta padetį, laikinai sustabdyti konstitucines piliečiu teisiu garantijas (\$S $12,13,15,16,17,18)$ ir imtis priemoniu pavojui atremti ar pašalinti, vartojant ir ginkluota pajega.

28 Kilus karui, ginkluotam sukilimui ar kitokiems pavojingiems neramumams Valstybëje, Ministeriu Kabinetui pasiūlius, Respublikos Prezidentas gali visoje Valstybeje arba tam tikrose jos dalyse ¡̇vesti karo arba kita kuria nepaprastą padetį, laikinai sustabdyti konstitucines piliečiu teisiu garantijas $(11,12,14,15,16,17 \$ \$)$ ir imtis priemoniu pavojui atremti ar pašalinti, vartojant ir ginkluotą pajega, ir tuo pat metu apie visa tai turi pranešti Seimui, kuris tą Vyriausybès žingsni tvirtina arba atmeta. 
Konstitucija buvo mechaniškai nurašyta nuo 1922 m. Konstitucijos, atsisakant tam tiktų valstybės valdžiai nepalankių, jos valdingus ịgaliojimus ribojančių nuostatų. Vadinasi, eliminavus Seimo dalyvavimą nepaprastosios padèties įvedimo procedūroje, buvo sukurtas mechanizmas, leidžiantis Prezidento rankose sutelkti sprendimą dèl karo padèties ịvedimo ir taip sustabdyti konstitucines piliečių teisių garantijas, tarp jų ir draugijų (politinių partijų), susirinkimų, spaudos laisves.

Situacija dar labiau pasikeitè Seimui 1938 m. vasario $11 \mathrm{~d}$. be debatų prièmus naują Konstituciją $^{30}$. Šiai Konstitucijai būdingas visiškas piliečių nušalinimas nuo dalyvavimo valstybès valdyme, vykdomosios valdžios, pirmiausia Prezidento, galios sustiprinimas, kuris reiškè vadizmo konstitucinị ịteisinimą. 1938 m. Konstitucijoje jau nedeklaruojama laisvė jungtis ị draugijas, susirinkimų, spaudos laisvè, o priešingai - iškeliama piliečio pareiga valstybei: Konstitucijos 17 straipsnis numate, kad pilietis naudojasi savo laisve, nepažeisdamas kito teisių ir visuomet atsimindamas savo pareigas valstybei. Taip konstituciniu lygmeniu buvo įtvirtinta piliečio pareiga būti ištikimam valstybei; be to, Konstitucijos 25 straipsnis deklaravo, kad valstybè saugo piliečių visuomeninio veikimo laisvę, ypač spaudoje, draugijose ir susirinkimuose, žiūrèdama, kad jis nebūtų veikiamas kenksminga valstybei kryptimi. 1938 m. Konstitucija iškeldama valstybès interesą prieš žmogaus iš esmès paneigè vieną pagrindinių demokratinès valstybės principų, iki tol ịtvirtintų Lietuvos konstitucijose, t. y. valstybè tarnauja žmogui. K. Račkauskas, kritikuodamas toki konstitucinį reglamentavimą, teigé, kad „Kas yra kenksminga valstybei, o ypač kokia ta veikimo kryptis, kuri yra valstybei kenksminga, yra nekonkrečios ir nejuridinès sąvokos. Sunku surasti du žmones, kurie dèl jų būtų vienos nuomonès. Šių sąvokų turinys priklauso nuo to, kokių pasaulèžiūrų yra prezidentas, vidaus reikalų ministeris ir net vietos policijos viršininkas. Tokiais perdaug bendrais aptarimais bei ịpareigojimais valdantieji igalinami savivaliauti ir griaunama teisinès valstybès ideja. "31 K. Račkauskas teigè, kad visose konstitucijose buvo užtikrinama politine lygybẻ balsuoti ir būti renkamam, tačiau vertindamas praktinị šių teisių veikimą, konstatavo, kad 1928 ir 1938 metų konstitucijose piliečio teisès politinio veikimo srityje buvo suvaržytos ir lygybès nebuvo ${ }^{32}$. Apibendrinant pasakytina, kad Konstitucijos normos per se nepanaikino demokratinių teisių ir laisvių, tačiau iškèlus valstybès primatą prieš žmogų, susiaurinus parlamento igaliojimus ir apribojus tautos dalyvavimą šalies valdyme, buvo sukurtos palankios sąlygos varžyti demokratines teises ir laisves.

Be to, padaryti konstituciniai pakeitimai iš esmès konstituciniu lygmeniu sankcionavo tai, kas jau buvo sukurta kitais teisės aktais ir administracinėmis priemonemis. Matyt, neatsitiktinai $1919 \mathrm{~m}$. Istatymas apie draugijas veikè net iki tol, kol $1936 \mathrm{~m}$. vasario $1 \mathrm{~d}$. Draugijų i̇statymo ${ }^{33} 69$ straipsniu buvo panaikintas, t. y. praejjus beveik dešimčiai metų po perversmo. Tautininkų administracija pasinaudojo nepaprastosios padèties institutu, jo netobulu reglamentavimu, İstatymo apie draugijas teisinių sąvokų dviprasmiškumu, pernelyg plačiomis dispozicijos teisemis, sutelktomis administracijos rankose šalyje tvarkytis

30 Seimo stenogramos, IV papr. sesija, 69 pos., $1938 \mathrm{~m}$. vasario 11 d., p. 35-42.

31 Račkauskas, K. Lietuvos konstitucinès teisés klausimais. New York, 1969, p. 76-77.

32 Ibid., p. 67-69.

33 Draugijų ịstatymas. Vyriausybès žinios. 1936, Nr. 522-3626. 
jiems patogiais metodais, taip išvengiant būtinybès iš karto po perversmo priimti naujus teisès aktus, reglamentuojančius draugijų veiklą.

Kita vertus, reikia pripažinti, kad naujasis Draugijų įstatymas deklaravo ir modernius demokratinès valstybès principus. Pavyzdžiui, įstatymo 37 ir 38 straipsniai deklaravo vieną pagrindinių demokratinès valstybès - laisvès jungtis ị draugijas - principą, kurio neaptare 1919 m. İstatymas apie draugijas. Buvo nustatyta, kad niekas negali būti verčiamas priklausyti draugijai, negali būti varžoma draugijos nario išstojimo iš draugijos teisè. Istatymas deklaravo laisvès jungtis ị draugijas principą. Reikšmingas ir Draugijų ịstatymo 63 straipsnis, numatęs, kad ne Lietuvos piliečių draugija neturi teisès vykdyti jokios politinės veiklos. Šis straipsnis imperatyviai nustatė, kad politinès partijos ir kitos politine veikla užsiimančios draugijos gali būti sudarytos išimtinai iš Lietuvos piliečių. Toks ittvirtinimas įstatymu vertintinas kaip ganètinai modernus valdžios suverenumo garantas, mechanizmas, saugantis nuo galimų užsienio valstybių politinės įtakos. Nepaisant šių modernių demokratinès valstybės principų deklaravimo, ịstatyme buvo normos, kurios, kaip matysime vèliau, iš esmès paneigè svarbiausius teisinès demokratinès valstybès principus.

Draugijų ịstatymas nustatė ir draugijų, jų padalinių steigimo tvarką, veiklą ir uždarymą. İstatymo 9 straipsnis suteikė vidaus reikalų ministrui teisę tvirtinti draugijos įstatus ir ịrašyti ị draugijų registrą. İstatymas numatė, kad tik draugija, kuri yra ịrašyta ị registrą, galèjo būti laikoma įsteigta ir turejjo teisę pradèti veikti. Draugijos padaliniams steigti taip pat buvo reikalingas vidaus reikalų ministro sutikimas, todèl ir draugijos padalinys turèjo būti ịrašomas ị draugijų registrą. Pasakytina, kad ịstatymo 18 straipsnis suteikè plačias teises vidaus reikalų ministrui valstybės ar tautos saugumo arba kitų valstybės ar tautos reikalų sumetimais nušalinti draugijos ar jos padalinio vadovybę arba atskirus vadovybès narius.

Bene daugiausiai diskusijų sulauke įstatymo straipsniai, išplètę duomenų sąrašą, kuris turi būti nurodomas įstatuose, lyginat su $1919 \mathrm{~m}$. İstatymo apie draugijas analogišku trečiuoju straipsniu ir tuo pretekstu imperatyviai nurodę pertvarkyti draugijų ịstatus pagal ịstatymo reikalavimus ir juos iki $1936 \mathrm{~m}$. balandžio $1 \mathrm{~d}$. pristatyti vidaus reikalų ministrui. Prisidengiant šiais formaliais reikalavimais, buvo numatyta, kad draugijai nepristačius pertvarkytų ịstatų laiku arba pristačius, tačiau iki 1936 m. liepos 1 d. negavus vidaus reikalų ministro leidimo veikti, draugija turèjo būti laikoma uždaryta. Teorijoje pabrèžiama, kad toks politinių partijų pripažinimas nulemtas naujo valstybès teisinio reglamentavimo, kuriuo îpareigojama politines partijas informuoti apie savo poreikius ir veiklą, taip gaunant ne tik valstybés juridinị pripažinimą, bet kartu atkreipiant dèmesị ị leidimą politinėms partijoms užsiimti savo veikla ${ }^{34}$. Šiomis, iš pirmo žvilgsnio nereikšmingomis îstatymo korekcijomis valstybės administracijai buvo sukurtos prielaidos uždaryti visas valdžiai neittikusias draugijas.

Deja, bet nepaisant deklaratyvių laisvès jungtis ị draugijas nuostatų, naujasis Draugijų ịstatymas išplètė draugijos veiklos sustabdymo galimybes. Istatymo 46 straipsnis nustatè, kad apskrities viršininkas turi teisę ịspèti ar sustabdyti draugijos ar jos padalinio veikimą, kai draugija ar jos padalinys nesilaiko įstatų arba nevykdo Draugijų įstatymo reikalavimų. Draugijos arba jos padalinio veikimas tokiu atveju sustabdomas, kol bus 
pašalinta sustabdymo priežastis. Jeigu ta priežastis nepašalinama per šešis mènesius, tai vidaus reikalų ministras iggyja teisę tą draugiją ar padalinị uždaryti. Be to, Draugijų ịstatymo 47 straipsnis vidaus reikalų ministrui suteikẻ teisę uždaryti draugiją, kai ji ar jos padalinys neturi teisètos vadovybès. Dar daugiau, vadovaujantis ịstatymo 48 straipsniu, vidaus reikalų ministras valstybės ar tautos saugumo arba „kitų valstybės ar tautos reikalų sumetimais" turi teisę sustabdyti draugijos ar jos padalinio veikimą iki pusès metų arba uždaryti draugiją ar jos padalinį.

Reikia pripažinti, kad nors priimtame įstatyme gausu deklaratyvių laisvės jungtis i draugijas, politinių laisvès nuostatų, tačiau praskleidus „deklaracijų šydą“ galima pamatyti, kad jos iš tikrųjų yra neapsaugotos, o naujasis draugijų teisinis reglamentavimas išplètojo mechanizmus, leidžiančius valstybės administracijai labiau kontroliuoti draugijų veiklą, o draugijas, siekiančias priešiškų valstybès valdžiai tikslų, uždaryti arba neduoti joms leidimo veikti. Be to, pasirinktas teisinio reglamentavimo modelis sukūrè patogias teisines ir administracines priemones, leidžiančias eliminuoti nepalankias, kritikuojančias esamą valdymą, politines partijas ir užkirsti kelią galimai opozicijai įsisteigti, taip sudarant tinkamas sąlygas vienpartinei sistemai formuotis. Atsižvelgiant $\mathfrak{i}$ tai, kas išdèstyta, ir tai, kad naujosios redakcijos įstatyme pagrindinis dèmesys buvo sutelktas ị draugijos veiklos kontrolès ir jos likvidavimo reglamentavimą, bei turint omenyje to meto politines aplinkybes, šie pakeitimai igijo antidemokratinị atspalvị.

Šiame kontekste prisiminus tai, kad 1926 m. gruodžio 17 d. tautininkų ịvesta karo padètis veikè visoje Lietuvos teritorijoje nuolatos, natūralu, kad kyla pagrịstų abejonių dèl konstitucinių teisių ir laisvių, tarp jų ir politinių, realaus užtikrinimo Lietuvoje. Ivertinus minėtąsias aplinkybes, nenuostabu, kad, esant nepaprastajai padèčiai šalyje, vidaus reikalų ministras pasinaudojo jam Draugijų ịstatymo suteikta teise „valstybės ar tautos saugumo arba kitų valstybès ar tautos reikalų sumetimais" sustabdyti draugijų veiklą iki pusès metų arba jas uždaryti. Ruošdamiesi $1936 \mathrm{~m}$. Seimo rinkimams, tautininkai pamažu perejo prie vienpartinès sistemos: $1935 \mathrm{~m}$. lapkričio $7 \mathrm{~d}$. spaudoje pasirodè pranešimai, jog valstybės saugumo institucijos pastebėjo, kad „opozicinių partijų: Lietuvos valstiečių liaudininkų ir Lietuvos krikščionių demokratų centro komitetai, pasinaudodami paskutiniu metu priešvalstybinio elemento kai kuriose vietose visuomenès rimties drumstimu, savo organizacijų veiklą pradejo vystyti kenksminga valstybei linkme. <...> Karo komendantas <...> nutarimu nr. nr. 627, 628 šių metų lapkričio 6 d. Lietuvos krikščionių demokratų ir Lietuvos valstiečių liaudininkų partijų veikimą sustabdè visam karo stovio metui“"35. Praejjus vos keliems mènesiams po šio pranešimo, Lietuvos naujienų agentūra išplatino kitą pranešimą, informuojantị, kad 1936 m. ,,vasario 6 d. nutarimais uždaré Lietuvių krikščionių demokratų partiją, Lietuvos socialdemokratų partiją, Lietuvos valstiečių liaudininkų sąjungą, Lietuvos jaunimo sąjungą ir Lietuvos ūkininkų vienybę su visais tų organizacijų

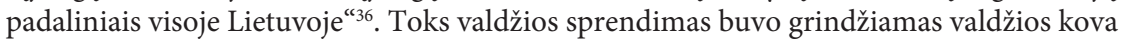
siekiant ịveikti ,„̌̌alingą tautai ir valstybei susiskaldymą“, buvo teigiama, kad uždarytosios organizacijos veikè prieš ,,esamą krašte tvarką“, „,ne tik nèjo vyriausybei ị talką tame

35 Sustabdytas liaudininkų ir krikščionių demokratų partijų veikimas. Lietuvos aidas. $1935 \mathrm{~m}$. lapkričio 7 d., Nr. 263(2526), p. 1. Tautos vienybès keliais. Lietuvos aidas. 1936 m. vasario 7 d., vakarinè laida, Nr. 61(2677), p. 1. 
svarbiame tautos vienybės ugdymo darbe, bet visokiais būdais ši darbą trukdë“, jos buvo kaltinamos, kad ,sieke pakirsti tautiškosios vyriausybės autoritetą, diskredituoti ją visuomenès akyse, platinamos slapta ir atvirai nukreiptus prieš vyriausybę atsišaukimus arba stačiai skleisdamos įvairius keliančius nerimą gandus ir prasimanymus“. Buvo bandoma ịrodyti, kad „organizacija <...> savo opozicingume išsigime““ ir dèl to yra būtina uždaryti šias visuomenei ir valstybei kenkiančias organizacijas; įrodinejama, kad „išejusių iš lojalaus veikimo ribų (Lojalumo kam? Esamiems de facto įstatymu reikalavimams, priimtiems nesilaikant demokratiniu valstybés principų? - aut. pastaba) organizacijų uždarymas" turi būti suprantamas kaip siekimas darnumo, vienybès Lietuvoje. Apeliuojant i tautiškumą ir šalies nepriklausomybę, buvo aiškinama visuomenei, kad pasirinktos priemonès yra tautos labui: „mes, nedidelè tauta, turime rūpintis, kad mūsų pajejgos nebūtų eikvojamos vidinèms partijų rietenoms, o tuo labiau kovai su rimties ir tvarkos ardymu, kuri gali pražudyti mūsų nepriklausomybę “37. Atkreiptinas dèmesys ị tai, kad nepaisant to, kad uždarytosios organizacijos buvo laikomos pažeidžiančios tautos vienybę, keliančios grèsmę valstybès ir tautos saugumui, tačiau buvo deklaruojama, kad pats savaime organizacijų steigimasis ir jų veikla nèra žalinga, maža to - yra toleruotinas ir sveikintinas, jei šios organizacijos bus lojalios ir „,prisidès prie valstybès ir tautos kuriamojo darbo“. Taip $1936 \mathrm{~m}$. vasario $6 \mathrm{~d}$. remiantis Draugijų ịstatymo 48 straipsniu ministras paskelbė visų partijų, išskyrus tautininkų sąjungų, uždarymą ${ }^{38}$.

Tuo pat metu, kai buvo pakeistas draugijų teisinis reglamentavimas, pakeisti ir rinkimus reglamentuojantys įstatymai. J. Robinzonas analizuodamas rinkimų teisès raidą po tautininkų perversmo teigè: ,łstatymų leidejjas, išleisdamas naująji $1936 \mathrm{~m}$. gegužès 9 d. rinkimų įstatymą, buvo susirūpinęs iš šios valstybès srities pašalinti politinių partijų varžymąsi su visais, kartais nesveikais, šio varžymosi reiškiniais ar padariniais. “39 1936 m. Seimo rinkimų ịstatymas numatè, kad rinkimuose tarp savęs turi varžytis ne politinès partijos, o ị rinkimų apygardos teritoriją ịeinančių apskričių ir joms prilygintų didžiųjų miestų tarybos keliami kandidatų sąrašai. Galutiniai rinkimų rezultatai buvo nustatomi mandatus tarp sąrašų paskirstant proporcingai surinktiems balsams už kiekvieno sąrašo kandidatus. İstatymas leido konkurenciją ir proporcinị mandatų skirstymą tiktai tarp kandidatų ir sąrašų, neturinčių jokių socialinių grupių ar kitų atstovavimo požymių. Toks Seimo rinkimų teisinis reglamentavimas įtvirtino vietos savivaldybèms monopolinę teisę siūlyti kandidatus ir iš rinkimų proceso visiškai eliminavo politines partijas. M. Romeris vertindamas teisini politinių partijų veiklos ir rinkimų reglamentavimą, priimtą po perversmo, rašè: ,„politinių partijų bei jųjų organų nariai <...> buvo ne kas kita, kaip politinių partijų ekspozitūros" ${ }^{\text {"40 }}$. Jis pabrèžè politinių partinių kandidatūrų siūlymo tiesioginiu būdu reikšmę, kaip vieną iš tiesioginès demokratijos instrumentų šalyje, kuri realiai po tautininkų perversmo buvo paneigta. Nors profesorius pripažino, kad formaliai naujoji rinkimų sistema panaši ị proporcinę atstovavimo sistemą, tačiau Seimo rinkimų įstatyme buvo nustatyta rezultatų apskaičiavimo tvarka, kuri vietoj partinès kandidato priklauso-

37 Partijos uždarytos. Lietuvos aidas. 1936 m. vasario 7 d., rytinè laida, Nr. 60 (2676), p. 1.

38 Ibid.

39 Robinzonas, J. Naujos konstitucijų revizijos Europoje 1933-1935 m. Teisé. 1936, 34: 218.

40 Romeris, M. 1936 metų Seimo rinkimo ịstatymas. Teisé. 1936, 35: 226-227. 
mybès pripažino tiktai jo teritorinę priklausomybę, taip sumažinant galimybę susidaryti organizuotai opozicijai. Vertindamas šią situaciją P. Leonas yra pažymėjęs, kad, nors ir yra ,panaši ị seimą ịstaiga, bet iš tikrųjų visa valstybės valdžia priklauso vienam asmeniui, kurio visi turi klausyti, kurio išreikštų minčių ir darbų nevalia kritikuoti“41. Pripažintina, kad tokia politine ir juridinè situacija Lietuvoje užkirto kelią galimam opozicijos atsiradimui, politiniam pliuralizmui, o tai iš esmès panaikino pačios partinès sistemos ir teisinès valstybès esmę.

Istatymų leidejjas nusisuko nuo demokratijos, tai ịtvirtino ne tik pasitelkdamas nepaprastosios padèties institutą, bet ir valstybès administracinị aparatą, turintị plačias diskrecijos teises. Pavyzdžiui, apskričių komendantams buvo išplatintas krašto apsaugos ministro aplinkraštis, kuriame buvo numatyta kiek galima atsargiau duoti leidimus tokiems susirinkimams, kuriuose, apskričių viršininkų bei kriminalinės policijos nuomone, galima laukti kokių nors nepageidautinų ,,išsišokimų“ arba agitacijos prieš rinkimus; jeigu yra bet kokių duomenų, kad tai gali atsitikti susirinkimuose, kuriems ịvykti jau buvo duoti leidimai, kad ir kitais tikslais, tuos leidimus buvo ịpareigota atšaukti; pavesta griežtai cenzūruoti spaudą, kad būtų išvengta agitacijos prieš rinkimus ir kokių išsišokimų ${ }^{42}$.

Politinių partijų varžymąsi buvo siekiama eliminuoti ịvairiais būdais: ne tik pasitelkiant, užkertančius kelią galimam opozicijos atsiradimui nacionalinius teisès aktus, valstybės administraciją su plačiais, nepaprastosios padeties sąlygomis turimais, igaliojimais, bet ir bauginant, spaudžiant politinių partijų narius, jų rẻmejjus. Pavyzdžiui, Lietuvos socialdemokratų partijos skunde vidaus reikalų ministrui buvo nurodoma, kad partijos nariams, kurie pradeda rūpintis organizacijos reikalais, policija „tiesiog i akis sako“, kad liautųsi dirbę, jei nenori „supūti“ kalèjime. Nariai, kurie išdrịsdavo nepaklusti, tikrai atsidurdavo kalejime, o partijos nariai, kuriems buvo iškeltos bylos, bet Kariuomenès teismo išteisinti, buvo nebepriimami ị savo senas tarnybas, kur jie dirbo prieš pradedant bylą prieš juos ${ }^{43}$.

Darytina išvada, kad taip sulig kiekviena įstatymo, reglamentuojančio politinių partijų steigimą ir veiklą, redakcija buvo supaprastinamos konstitucinių teisių ir laisvių ribojimo galimybès, didinama šių ribojimų apimtis. Vykdomoji ir karinè valdžia savo rankose sutelkè vis daugiau galių. Todèl nenuostabu, kad nepaprastosios padèties taikymas tarpukario Lietuvoje kelia pagrịstų abejonių dèl jos taikymo apimties proporcingumo ir pagrịstumo. Reikia pripažinti, kad nors iki tautininkų perversmo šis institutas sudarė sąlygas greitai reaguoti į nestabilią situaciją po Pirmojo pasaulinio karo šalies viduje ir išorèje, tačiau po $1926 \mathrm{~m}$. jis igijo jau ne tautos ir valstybès apsaugos, o valstybės vadovo valdžios stiprinimo, jos apsaugos ir politinių teisių ribojimo pobūdị. Šalies valdžia, pasinaudodama minimalius demokratijos standartus atitinkančiomis, tačiau pernelyg plačiai, dviprasmiškomis sąvokomis apibrěžtomis, ịstatymo nuostatomis, neužkertančiomis kelio galimiems nesąžiningiems piktnaudžiavimams teise, prièmé sprendimus, kurie iš esmès

41 Romeris, M. 1936 metų Seimo rinkimo įstatymas. Teisè. 1936, 35: 265.

42 Lietuvos Respublikos krašto apsaugos ministerijos 1931 m. lapkričio 25 d. aplinkraštis Nr. $916 /$ s1. Lietuvos centrinis valstybès archyvas. F. 394, ap. 15, b. 248, 1. 57.

43 Lietuvos socialdemokratų partijos Centro komiteto pareiškimas $1931 \mathrm{~m}$. vasario $28 \mathrm{~d}$. Vidaus reikalų ministrui dèl Lietuvos socialdemokratų partijos veikimo trukdymų. Lietuvos centrinis valstybès archyvas. F. 394, ap. 15, b. 200, 1. 90. 
paneigè teisinès valstybės, kaip demokratijos formos, esmę. Taip dar kartą patvirtinant, kad nudum jus neturi jokio realaus efekto. Kadangi po tautininkų perversmo buvo sukurta teisinè sistema, kuri neturejjo pakankamai išvystytų juridinių garantijų, užtikrinančių valdžios paklusimą teisei, pasinaudojant teisès aktų netobulumu ir itin plačia diskrecijos teise, sutelkta valstybès administracijos pareigūnų rankose, buvo paneigti politinès laisvès, laisvo draugijų, politinių partijų steigimosi ir veikimo principai. Taip, nors de jure neuždraudžiant, buvo užkirtas kelias ne tik galimam opozicijos atsiradimui, bet ir panaikinta pati partinès sistemos, teisinès valstybès esmè.

\section{Išvados}

1. Iki 1920 m. vykusių Steigiamojo Seimo rinkimų buvo priimti visi rinkimus, politinių partijų steigimąsi ir veiklą reglamentuojantys teisès aktai, paklojantys pamatus daugpartinès sistemos vystymuisi šalyje. Nors ịstatymų leidejo pasirinktas reglamentavimo modelis vertintinas kaip atitinkantis demokratinès valstybès reglamentavimo standartus (juridiškai įtvirtintas laisvas politinių partijų steigimasis ir veikimas, reglamentuotos galimybès dalyvauti politinėje kovoje dèl valdžios), tačiau pripažintina, kad demokratinị režimą Lietuvoje kompromitavo nepaprastosios padèties taikymo nuolatinumas.

2. 1926-1940 m. politinių partijų teisinis reglamentavimas pamažu nutolo nuo demokratinès valstybès reglamentavimo standartų, palaipsniui sudarant juridines sąlygas veikti tik vienai politinei partijai. Opozicinès politinès partijos buvo nušalintos nuo dalyvavimo politinèje kovoje dèl valdžios.

3. 1919-1940 m. politinių partijų teisiniam reglamentavimui būdingas neišsamumas, t. y. normos, reglamentuojančios politinių partijų veiklos ribojimo, uždarymo klausimus, neretai buvo gana dviprasmiškos arba pernelyg abstrakčios ir todèl suteikẻ plačią dispozicijos teisę valstybès aparato darbuotojams priimti sprendimus, turinčius įtakos saugomų žmogaus teisių apimčiai šalyje.

\section{Literatūra}

Beigbeder, Y. International monitoring of plebiscites, referenda and national elections. Self-determination and Transition to Democracy. International Studies in Human Rights Volume 32. London: Martinus Nijhoff Publishers, 1994.

Bonaudi, E. Pricipii di Diritto Pubblico. Torino: Unione tripografico - editrice torinese, 1936.

Draugijų ịstatymas. Vyriausybès žinios. 1936, Nr. 522-3626.
I Tautą. Respublikos Prezidento kreipimasis. Lietuvos Vyriausybès žinios. 1931, Nr. 369-2519.

Isakymas. Laikinosios Vyriausybès žinios. 1920, Nr. 20-253.

Istatymas apie draugijas. Laikinosios $V y$ riausybés žinios. 1919, Nr. 15-249.

Istatymo karo stoviui ịvesti pakeitimas. Vyriausybès žinios. 1922, Nr. 105-823.

Ypatingi valstybès apsaugos ịstatai. Laikinosios Vyriausybès žinios. 1919, Nr. 4-42. 
Ypatingi valstybès apsaugos įstatai. Laikinosios Vyriausybès žinios. 1919, Nr. 5-55.

Jankūnaitè, V. Lietuvos Valstybès Konstitucija su paaiškinimais. Neoficialus leidinys. Kaunas, 1922.

Karo stovio ịvedimo aktas. Vyriausybès žinios. 1926, Nr. 242-1582.

Laikinosios Lietuvos valstybès Konstitucijos papildas. Laikinosios Vyriausybes žinios. 1919, Nr. 4.

Leonas, P. Teisès enciklopedijos paskaitos. Teisès sociologijos paskaitos. Raštai. II tomas. Vilnius: Teisinès informacijos centras, 2005.

Lietuviu tautos valia (vienkartinis leidinys), $1927 \mathrm{~m}$. vasario $1 \mathrm{~d}$.

Lietuvos centrinis valstybès archyvas:

fondas 394 - Vidaus reikalų ministerijos Policijos departamentas apyrašas 15, bylos 97, 200, 248; apyrašas 3, byla 799 .

Lietuvos Konstitucija. Vyriausybès žinios. 1938, Nr. 608-4271.

Lietuvos Valstybės Konstitucija. Vyriausybés žinios. 1928, Nr. 275-1778.

Maksimaitis, M. Karinių-administracinių organų savivalès ịteisinimas Lietuvoje 1919-1926 m. Ypatingais valstybès apsaugos įstatais. Lietuvos TSR moksly akademijos darbai. Serija A, Nr. 1(12). Vilnius: Valstybinè politinès ir mokslinès literatūros leidykla, 1962.

Marabuto, P. Les partis politiques et les mouvements sociaux sous la IV République. Historique- Organisation. Doctrine-Activité. Paris: Librairie du Recueil Sirey, 1948.

Naująją erą pradedant. Tautos kelias. 1928 m. birželio 1 d., Nr. 9.

Nepaprastojo meto įstatymas. Vyriausybès žinios. 1939, Nr. 644-4702.

Nepaprastojo meto istatymo pakeitimas. Vyriausybés žinios. 1939, Nr. 662-4849.

Partijos uždarytos. Lietuvos aidas. 1936 m. vasario 7 d., rytinè laida, Nr. 60 (2676).
Pavilonis, Vl. Buržuazinio demokratinio režimo Lietuvoje klausimu. Lietuvos TSR aukštuju mokyklu mokslo darbai. Teise. 1966, VI.

Račkauskas, K. Lietuvos konstitucinès teises klausimais. New York, 1967.

Respublikos Prezidento aktai. Vyriausybes žinios. 1938, Nr. 627-4504.

Respublikos Prezidento aktas. Seimo paleidimo aktas. Vyriausybès žinios. 1927, Nr. 253-1652.

Respublikos Prezidento aktas. Vyriausybes žinios. 1926, Nr. 242-517a.

Respublikos Prezidento aktas. Vyriausybès žinios. 1938, Nr. 624-4461.

Respublikos Prezidento aktas. Vyriausybes žinios. 1939, Nr. 637-4643.

Robinzonas, J. Naujos konstitucijų revizijos Europoje 1933-1935 m. Teisè. 1936, 34.

Romeris, M. Lietuvos konstitucinès teisès paskaitos. I d. Kaunas, 1937.

Romeris, M. Lietuvos konstitucinès teisés paskaitos. Vilnius: Mintis, 1990.

Römeris, M. Valstybè. II tomas. Vilnius: Pradai, 1995.

Romeris, M. 1936 metų Seimo rinkimo istatymas. Teise. 1936, Nr. 35.

Seimo rinkimų įstatymas. Vyriausybès $\check{z} i$ nios. 1922, Nr. 98-793.

Seimo stenogramos, IV papr. sesija, 69 pos., $1938 \mathrm{~m}$. vasario $11 \mathrm{~d}$.

Sustabdytas liaudininkų ir krikščionių demokratų partijų veikimas. Lietuvos aidas. $1935 \mathrm{~m}$. lapkričio $7 \mathrm{~d}$., Nr. 263(2526).

Šileikis, E. Politiniu partijų institucionalizavimas. Partiju steigimas, registravimas, teisés, veiklos sustabdymas ir nutraukimas. Vilnius: Onè, 1997.

Vyriausiojo Tribunolo 1924-1933 metu visuotiniujų susirinkimu nutarimu rinkinys, 12. Kaunas, 1933. 


\title{
LITHUANIAN POLITICAL PARTY IN THE LEGAL REGULATION OF 1919-1940
}

\author{
Kristina Ivanauskaitè \\ Mykolas Romeris University, Lithuania
}

Summary. The main goal of this article is to highlight the Lithuanian political party system of legal regulation of formation of traditions and the disclosure of the legal framework in 1919-1940. This article discusses examination of the development of Lithuanian party system and identifies common patterns.

The research is focused on the analysis of the legal regulation of the system of Lithuanian political party. The author discusses legal and historical issues and takes no notice of the issue of political considerations. The author also discusses the historical and political circumstances, which prompted the current legal framework, examines the influence of party system evolution of the statehood of Lithuania and the development of constitutionalism.

There are a few authors, who made some researches on a few legal issues, e.g., in the monograph by Professor M. Romeris ("Lietuvos konstitucinès teises paskaitos", 1937), the development of political regime and its influence on the political party system was discussed. His monograph "Reprezentacija ir mandatas" (1926) studied the legal regulation of election and its influence of representation of citizenships in the government of the country. One of the most relevant to the subject of the research studies was conducted by E. Sileikis ("Politiniu partiju instucionalizavimas", 1997), where he presented the historical development of regulation of political parties in Lithuania and outlined the significance of modern political parties more extensively. In J. Bulavas' monograph ("Rinkimai ir 'tautos atstovavimas' buržuazineje Lietuvoje”, 1956), the legal status of political parties, military and emergency and high-security conditions in Lithuania during the interwar period were analyzed. His monograph „Klasès ir politines partijos Lietuvoje 1919-1926 metais“ (1978) studied the legal regulation of the political parties in the independent Lithuania.

This article analyzes the normative legal acts of the independence period of Lithuania, which have regulated the formation of political parties, the legal framework of their activities and meetings. These normative legal acts' influence on the formation of the political party system of Lithuania is discussed. The research is made on the legalization process of illegal organizations and political parties. It pays attention to the changes of legal regulation of political parties and its dependence on the regime. Moreover, the article compares legal regulation in different periods of development of the regime of the Republic of Lithuania in 1918-1940. Furthermore, the comparison of the changes of legal regulation within the periods of 1918-1926 (the period of the democratic regime) and 1926-1940 (the period of the undemocratic regime) is made.

Keywords: association, political party, state of emergency, legal regulation. 
Kristina Ivanauskaitė, Mykolo Romerio universiteto Teisès fakulteto Teisès filosofijos ir istorijos katedros doktorantè. Mokslinių tyrimų kryptys: Lietuvos teisės istorija, Lietuvos partinès sistemos teisinis reglamentavimas.

Kristina Ivanauskaite, Mykolas Romeris University, Faculty of Law, Department of Philosophy of Law and Legal History, Doctoral Student. Research interests: Legal History of Lithuania, Development of Legal Regulation in Lithuanian Party System. 